\title{
The stratigraphic importance of the brontothere (cf. Diplacodon elatus) in the Brennan Basin Member of the Duchesne River Formation of Utah
}

\author{
B. J. Burger and L. Tackett II \\ Department of Geology, Utah State University, Uintah Basin Regional Campus 320 North Aggie Blvd. Vernal, \\ UT 84078, USA
}

Correspondence to: B. J. Burger (benjamin.burger@usu.edu)

Received: 10 June 2014 - Revised: 6 August 2014 - Accepted: 12 August 2014 - Published: 27 August 2014

\begin{abstract}
We report on the first occurrence of an early horned brontothere in the Brennan Basin Member of the Duchesne River Formation in northeastern Utah. This is the first record of a brontothere from the Brennan Basin Member. Previously, brontotheres have been reported from the higher stratigraphic La Point Member (Duchesneodus uintensis) and the lower stratigraphic Uinta Formation (Sphenocoelus uintensis, Fossendorhinus diploconus, Metarhinus fluviatilis, Metarhinus abbotti, Sthenodectes incisivum, Metatelmatherium ultimum, Protitanotherium emarginatum, Pollyosbornia altidens, Diplacodon elatus). The recovered specimen consists of an upper third molar, which is comparable to the species Diplacodon elatus. The specimen supports the continued presence of brontotheres throughout the deposition of the Duchesne River Formation across the late Uintan to early Duchesnean North American Land Mammal Age. The previous lack of brontotheres within the lower beds of the Duchesne River Formation is likely a result of poor sampling and the relative rarity of fossils from this unit.
\end{abstract}

\section{Introduction}

One of the most characteristic large mammals of the Eocene of North America are brontotheres (order Perissodactyla, family Brontotheriidae), also known as titanotheres. During the middle Eocene, brontotheres occupied many geographic regions of North America, from the Canadian High Arctic (Eberle and Storer, 1999; Eberle and Greenwood, 2012), southern California (Stock, 1935, 1936, 1937, 1938; Mihlbacher and Deméré, 2009, 2010), Texas (Stovall, 1948), southern Mississippia (Gazin and Sullivan, 1942), and the Pacific Northwest (Mihlbacher, 2007). But nowhere is the record of brontotheres as diverse as the fossil record obtained from the middle Eocene depositional basins located in northeastern Utah, southwestern Wyoming and northwestern Colorado (Lull, 1905; Cook, 1926; Douglass, 1909; Gregory, 1912; Gunnell and Yarborough, 2000; Hatcher, 1895; Lucas et al., 2004; Lucas and Holbrook, 2004; Lucas and Schoch, 1982; Mader, 2000, 2009a, b, Mihlbacher, 2008, 2011; Osborn, 1889, 1895, 1908, 1913, 1929; Peterson, 1914a, b, 1931, 1934; Riggs, 1912; Stucky et al., 1996).

Early workers, such as Osborn (1929), viewed the evolution of brontotheres as a stepwise progression, culminating in forms such as the large horned Megacerops. Osborn's progressive gradualistic view of the evolution of brontotheres depended on what Simpson (1961) called Osborn's extreme use of vertical classification and lack of regard for monophyly. Osborn's preconceived idea hinged on his generalized use of stratigraphic information, which was often limited among early fossil collections. But his greatest error was erecting numerous taxonomic names with separate points of origin. Much of Osborn's (1929) brontothere classification has been clarified by recent work of Mader (1989, 1998, 2008) and Mihlbachler (2008). Both Mihlbachler (2008) and Mader (2008) reviewed the systematics of the family, and Mihlbachler (2008) offered a cladistic study of the group clearing up much of the confusing taxonomy of Osborn (1929). Mihlbachler et al. (2004) advocated grouping late Eocene brontotheres from the Chadronian into two species of Megacerops, and a single species of Protitanops, but still left 18 genera of brontotheres in North America during the middle Eocene 
(Mihlbachler, 2008). Mader (2008) grouped Dolichorhinus within Sphenocoelus, and later Mader (2009b) grouped Fossendorhinus within Metarhinus, while Mihlbachler (2008) grouped Mader's (2000) Pseudodiplacodon and Eotitanotherium within Diplacodon. Despite these differences in the taxonomy of brontotheres, nearly half of brontothere genera known from North America occur during a very narrow time interval during the early Uintan Land Mammal Age (about 46 to 44 million years ago). Rock formations of this age are well exposed in the Uinta Basin of northeastern Utah, the Sand Wash Basin of northwestern Colorado, and the Washakie Basin of southwest Wyoming. This zone of high diversity is followed by a gap in the fossil record during the late Uintan Land Mammal Age (Uinta C2 of Osborn, 1929). During the Duchesnean Land Mammal Age, three genera - Duchesneodus (Peterson, 1931, 1934; Lucas and Schoch, 1982; DeBlieux et al., 2011) from Utah, Eubrontotherium from Oregon (Mihlbacher, 2007) and Parvicornus occidentalis from southern California (Mihlbacher and Deméré, 2009) - are known after this gap in the fossil record.

In this article we describe the first occurrence of an early horned brontothere in the lower portion of the Brennan Basin Member of the Duchesne River Formation in northeastern Utah. This is the first record of a brontothere from the Brennan Basin Member (see Rasmussen et al., 1999; Kelly et al., 2012, for a fauna list), and supports the continued presence of brontotheres in the Uinta Basin of northeastern Utah during the middle and late Eocene.

\section{Materials and methods}

The fossil described in this paper was discovered from an ongoing Utah State University project to sample fossils from the poorly represented middle Eocene Duchesne River Formation in northeastern Utah and to study in detail the mammalian fauna from this previously poorly sampled stratigraphic interval. The specimen described in this article was collected on public land managed by the Bureau of Land Management and deposited at the Utah Field House $\mathrm{Mu}-$ seum located in Vernal, Utah. Detailed locality information is on file with the Utah Geological Survey and the Utah Field House Museum. Research was conducted under permit \#UT12-001S issued to the senior author.

The recovered fossil specimen (FHPR 11763) is a complete right upper third molar (Fig. 1). The central molar fossa was fractured and repaired with polymer clay, but all the anatomical features of the occlusal surface can be discerned from original recovered material. The tooth features a large W-shaped ectoloph characteristic of brontotheres. The parastyle is prominent on the anterior buccal edge of the tooth, with a slightly bent anterior projection. The paracone and metacone are well preserved, with steep cutting edges on the lingual margins. The mesostyle is long, forming the mid-
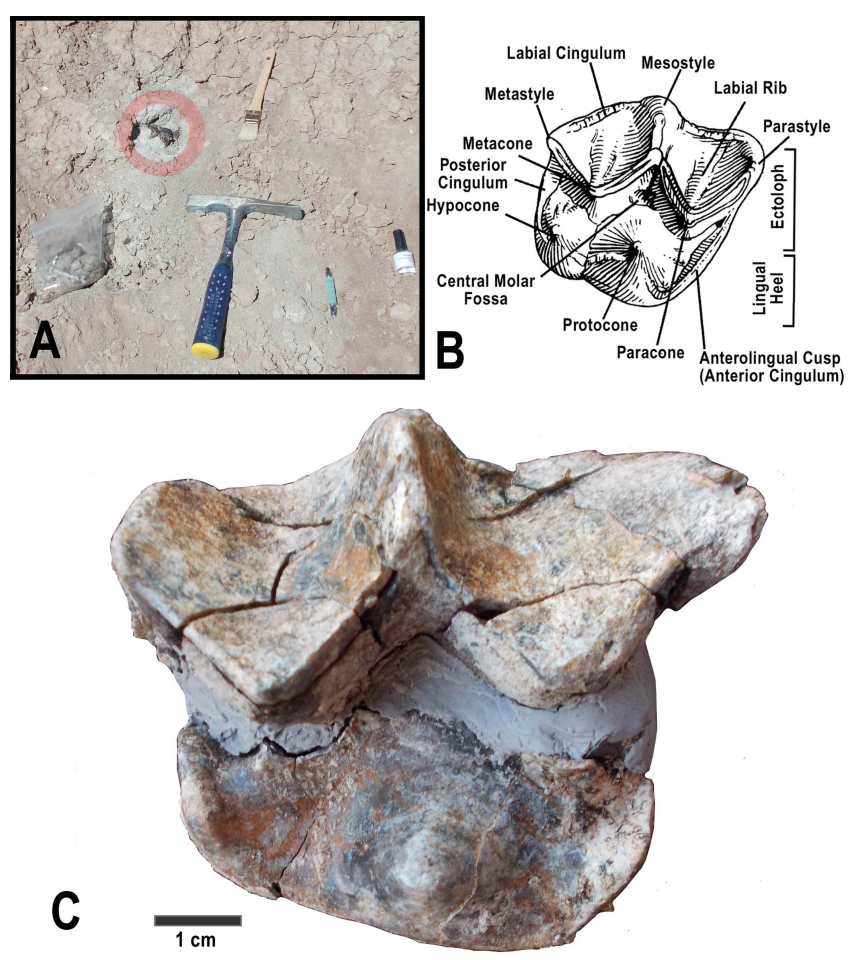

Figure 1. (a) Photograph of location of fossil discovered in situ. (b) Terminology used in the description of the upper molar. (c) Image of the specimen of cf. Diplacodon elatus collected from the Brennan Basin Member of the Duchesne River Formation. See the Supplement.

dle crest of the W-shape. The tooth lacks any distinct labial ribs along the buccal slope of the paracone and metacone.

The lingual heel of the tooth features a well-developed knobby protocone, flanked by two projections on the cingulum representing the hypocone on the posterior side, and a crest on the anterior cingulum, which is nearly, if not as large as, the hypocone. The tooth measures $60.0 \mathrm{~mm}$ in length and $57.0 \mathrm{~mm}$ in width.

The fossil was discovered in a smectic yellowish brown mudstone located near the head of Antelope Draw, close to the contact between the Uinta and Duchesne River Formations as mapped by Sprinkel (2007). The fossil was recovered below the sandstone interval that forms Glen Bench, a prominent topographic ridge in the eastern Uinta Basin. Thus, the fossil was recovered stratigraphically in the lower part of the Brennan Basin Member of the Duchesne River Formation. Kelley et al. (2012) place the Brennan Basin Member of the Duchesne River Formation in the late Uintan North American Land Mammal Age, and this age assessment seems consistent with fossils recovered from the Brennan Basin Member. This is the first occurrence of a brontothere from the Brennan Basin Member. Previously the upper La Point Member of the Duchesne River Formation was the only unit to produce brontotheres - a number of individuals 

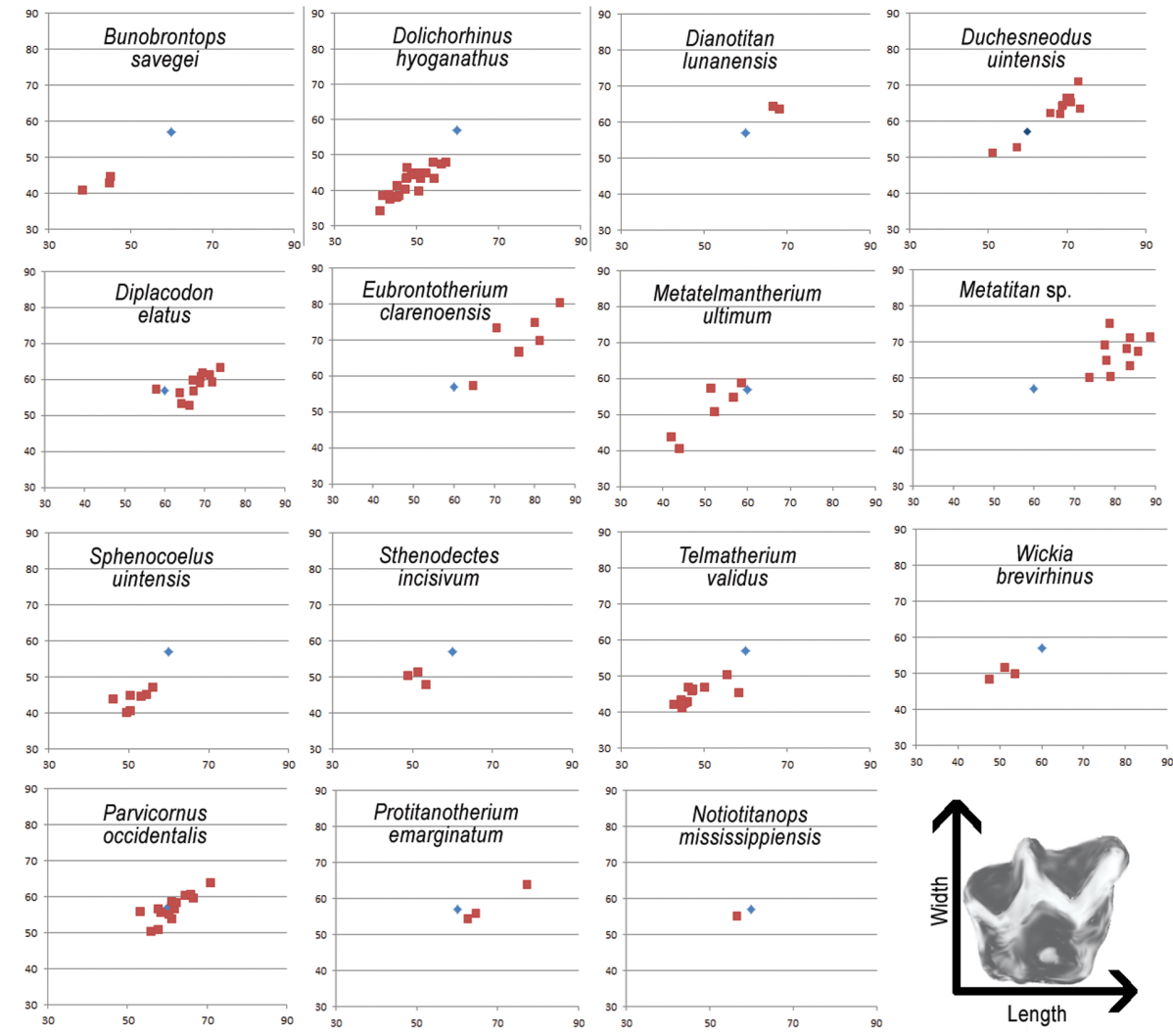

Figure 2. Graphs showing length and width of the upper third molar of brontothere species. Data come from published measurements from Mihlbachler (2008) and Mihlbacher and Deméré (2009). Blue diamond represents length and width of the recovered specimen from the Brennan Basin Member. All units in millimeters.

of Duchesneodus uintensis (Peterson, 1931, 1934; Lucas and Schoch, 1982). Currently, Duchesneodus uintensis is an index fossil for the later Duchesnean North American Land Mammal Age (Lucas, 1992; Robinson et al., 2004).

\section{Results}

Preliminary identification of the specimen was made by comparing the relative size and general morphology of the tooth (Fig. 2). The size of the newly recovered specimen most closely resembles that of Duchesneodus, Protitanotherium, Metatelmatherium, Notiotitanops, Diplacodon, and Parvicornus, and is much smaller than Eubrontotherium, Protitanops and Megacerops, and is significantly larger than Mesatirhinus, Metarhinus, Sphenocoelus and Telmatherium and other early brontotheres. Morphologically, Duchesneo$d u s$ contains a large fold on a prominent parastyle, which is lacking in the recovered specimen. In Protitanotherium and Notiotitanops the upper third molar lacks a well-developed anterior cingulum (anterolingual cusp), and the parastyle projects more lingually than observed in the recovered specimen. Metatelmatherium exhibits a much narrower third molar, with not as well-developed anterolingual and hypocone cusps. However, the recovered tooth demonstrates strong similarity with Parvicornus occidentalis and Diplacodon elatus. Both species exhibit a weakly developed hypocone on the posterior cingulum, and a raised anterior cingulum (anterolingual cusp) with a broad lingual heel. Parvicornus occidentalis from southern California exhibits a better developed hypocone than Diplacodon elatus and the new specimen. Mihlbacher and Deméré (2009) noted that, in Parvicornus occidentalis upper molars, the anterolingual cusp is only weakly developed in comparison to the broad cusp in Diplacodon elatus. The recovered specimen exhibits a broad anterolingual cusp. Hence, the specimen is provisionally identified as belonging to Diplacodon. Recently, Mihlbachler (2011) described a new $20 \%$ larger species of Diplacodon (D. gigan) from the Wiggins Formation in Wyoming. The only known specimen lacks a third upper molar. The recovered specimen is in the smaller size range for Diplacodon elatus, and likely does not belong to the larger D. gigan. While morphological and size traits do not necessarily result in a conclusive identification, there is support for recognizing the specimen as belonging to Diplacodon. Additional material, particularly cranial material, will help to confirm this identification, which should be seen as preliminary based on the available material. 


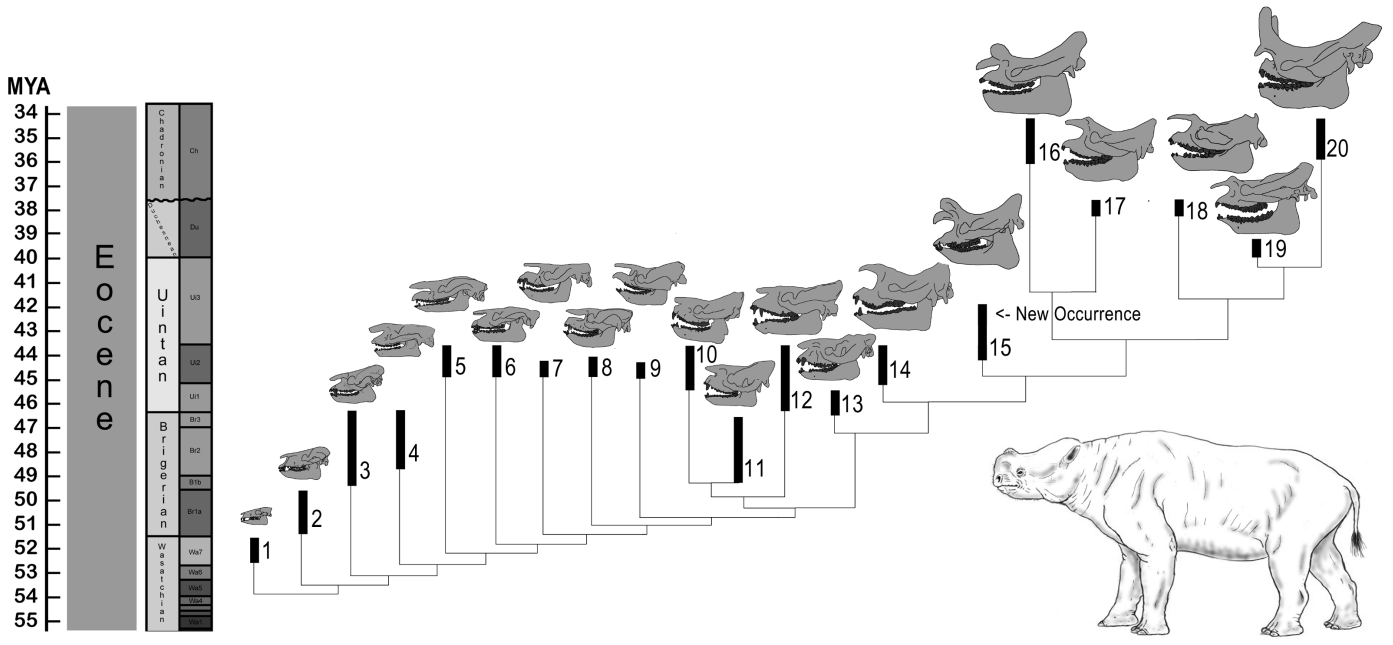

Figure 3. Stratigraphic occurrence and phylogeny of North American brontotheres, with reconstruction of Diplacodon elatus. Phylogenetic relationships follow that of Milhbacher (2008) and Mihlbacher and Deméré (2009). Skulls based on figures presented in Osborn (1929) and Milhbacher (2008). (1). Lambdotherium popoagicum, (2). Eotitanops sp., (3). Paleosyops sp., (4). Mesatirhinus megarhinus, (5). Dolichorhinus hyognathus, (6). Sphenocoelus uintensis, (7). Metarhinus fluviatilis, (8). Metarhinus abbotti, (9). Fossendorhinus diploconus, (10). Stenodectes incisivum, (11). Telmantherium validus, (12). Metatelmatherium ultimum, (13). Wickia brevirhinus, (14). Protitanotherium emarginatum, (15). Diplacodon elatus, (16). Protitanops curryi, (17). Eubrontotherium clarnoensis, (18). Parvicornus occidentalis, (19). Duchesneodus uintensis, and (20). Megacerops sp.

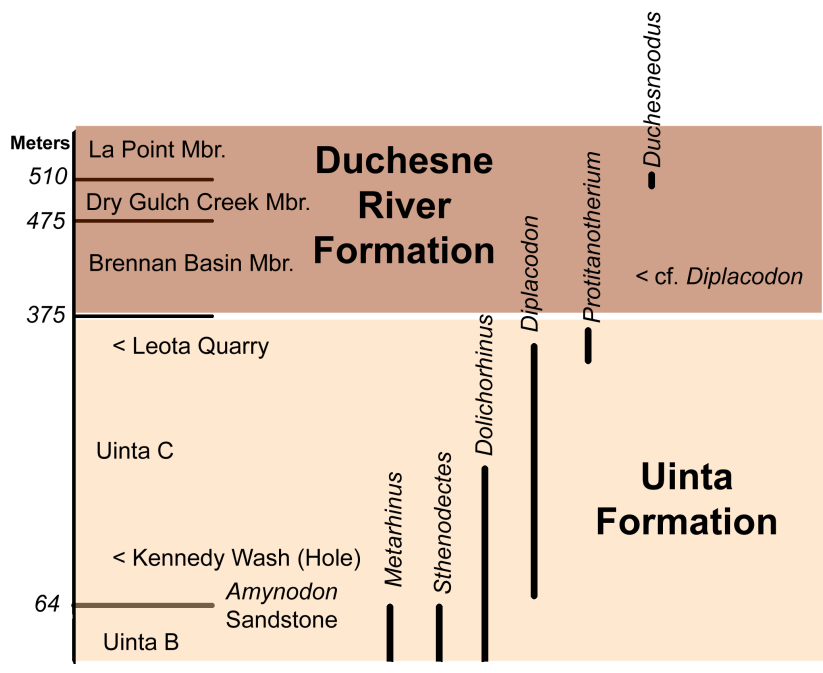

Figure 4. Stratigraphic position of brontotheres in northeastern Utah. Measure section of Uinta Formation based on Townsend et al. (2006).

\section{Discussion}

It is not surprising to find a specimen closely resembling Diplacodon occurring in the Brennan Basin Member of the Duchesne River Formation, given the occurrence of Diplacodon in the upper units of the underlying Uinta Formation (Osborn, 1929). However, this specimen is important in helping to establish a continuous record of brontotheres in North America, and by filling in a previously noted gap in the fossil record (Figs. 3, 4). Diplacodon elatus belongs to the monophyletic clade (subtribe Brontotheriina) which includes later Eocene brontotheres such as Megacerops, as well as the earlier Protitanotherium. Brontotheriina appears to have arisen in Asia during the late Uinta B time with a number of taxa entering into North America in the late Uin$\tan$ Age, but the exchange of genera between the continents likely continued into the upper Eocene (Mihlbachler, 2008). It is interesting to note that the Brontotheriina likely replaced the earlier more primitive brontothere fauna, replacing such genera as Dolichorhinus, Sphenocoelus, Metarhinus, Sthenodectes, and Metatelmatherium, which are known from the stratigraphically lower Uinta Formation, but have not been reported from higher stratigraphic units in the Uinta Basin. This change may reflect a significant ecological shift among the larger mammals during the transitional time between the Uintan to Duchesnean Land Mammal Ages, or it is a factor of poor sampling. Nevertheless, the new specimen is important for refuting any notion of the absence of brontotheres in North America during the late middle Eocene. Rather North America continued to foster brontotheres until their extinction at the end of the Eocene, and continued collection of fossil vertebrates from the Brennan Basin Member of the Duchesne River Formation will lead to a better picture of how the mammalian faunas in North American changed during the second half of the Eocene Epoch.

The Supplement related to this article is available online at doi:10.5194/fr-17-69-2014-supplement. 
Acknowledgements. Special thanks to Matthew Mihlbachler who read over this paper and provided insightful recommendations to an earlier draft. Steve Sroka at the Utah Field House Museum in Vernal provided a local repository for fossils recovered during this project, insuring this specimen remains with the community. Special thanks to the BLM, in particular Scott Foss, for their continued commitment to preserving vertebrate fossils on BLM administered lands in Utah. Research conducted under BLM permit \#UT12-001S.

Edited by: F. Witzmann

Reviewed by: A. Friscia and one anonymous referee

\section{References}

Cook, H. J.: New Eocene titanotheres from Moffat County, Colorado, Proceedings of the Colorado Museum of Natural History, 7, 12-18, 1926.

DeBlieux, D., Foss, S., Biek, R., Kuehne, P., and Willis, G.: New Eocene fossil perissodactyls from Thousand Lake Mountain, central Utah, Abstracts with Programs Geological Society of America, 43, p. 79, 2011.

Douglass, E.: Preliminary descriptions of some new titanotheres from the Uinta deposits, Annuals of the Carnegie Museum, 6, 304-313, 1909.

Eberle, J. J. and Greenwood, D. R.: Life at the top of the greenhouse Eocene world-A review of the Eocene flora and vertebrate fauna from Canada's High Arctic, Bull. Geol. Soc. Am., 124, 3-23, 2012.

Eberle, J. J. and Storer, J. E.: Northernmost record of brontotheres, Axel Heiberg Island, Canada: implications for age of the Buchanan Lake Formation and brontothere paleobiology, J. Paleontol., 73, 979-83, 1999.

Gazin, C. L. and Sullivan, J. M.: A new titanothere from the Eocene of Mississippi with notes on the correlation between the marine Eocene of the Gulf Coastal Plain and continental Eocene of the Rocky Mountain region, Smithsonian Miscellaneous Collections, 101, 1-13, 1942.

Gregory, W. K.: Note on the upper Eocene titanotheroid Telmatherium(?) incisivum Douglass from the Uinta Basin, Science, 35, p. $545,1912$.

Gunnell, G. F. and Yarborough, V.: Brontotheriidae (Perissodactyla) from the late early and middle Eocene (Bridgerian), Wasatch and Bridger Formations, southern Green River Basin, southwestern Wyoming, J. Vertebr. Paleontol., 20, 349-68, 2000.

Hatcher, J. B.: On a new species of Diplacodon, with a discussion of the relations of that genus to Telmatotherium, Am. Nat., 29, 1084-1090, 1895.

Kelly, T. S., Murphey, P. C., and Walsh, S. L.: New records of small mammals from the middle Eocene Duchesne River Formation, Utah, and their implications for the Duchesnean-Uintan North American Land Mammal Age transition, Paludicola, 8, 194-237, 2012.

Lucas, S. G.: Redefinition of the Duchesnean land mammal "age," late Eocene of western North America, in: Eocene-Oligocene Climatic and Biotic Evolution, edited by: Prothero, D. R. and Berggren, W. A., Princeton University Press, Princeton, NJ, 88$105,1992$.
Lucas, S. G. and Holbrook, L. T.: The skull of the Eocene perissodactyl Lambdotherium and its phylogenetic significance, in: Paleogene Mammals, edited by: Lucas, S. G., Zeigler, K. E., and Kondrashov, P. E., New Mexico Museum of Natural History and Science Bulletin, 26, 33-44, 2004.

Lucas, S. G. and Schoch, R. M.: Duchesneodus, a new name for some titanotheres (Perissodactyla, Brontotheriidae) from the late Eocene of western North America, J. Paleontol., 56, 1018-1023, 1982.

Lucas, S. G., Emry, R. J., and Mihlbachler, M. C.: Late Eocene brontotheres (Mammalia, Perissodactyla) from the Beaver Divide, Wyoming, and their biochronological significance, in: $\mathrm{Pa}-$ leogene Mammals, edited by: Lucas, S. G., Zeigler, K. E., and Kondrashov, P. E., New Mexico Museum of Natural History and Science Bulletin, 26, 113-118, 2004.

Lull, R. S.: Megacerops tyleri, a new species of titanothere from the badlands of South Dakota, J. Geol., 34, 443-456, 1905.

Mader, B. J.: The Brontotheriidae: a systematic revision and preliminary phylogeny of North American genera, in: The Evolution of Perissodactyls, edited by: Prothero, D. R. and Schoch, R. M., Oxford University Press, Oxford, 458-484, 1989.

Mader, B. J.: Brontotheriidae, in: Evolution of Tertiary Mammals of North America. Volume 1: Terrestrial Carnivores, Ungulates, and Ungulate-like Mammals, edited by: Janis, C. M., Scott, K. M., and Jacobs, L. L., Cambridge University Press, Cambridge, 525-536, 1998.

Mader, B. J.: Pseudodiplacodon, a new generic name for Diplacodon progressum Peterson (Mammalia, Perissodactyla, Brontotheriidae), J. Vertebr. Paleontol., 20, 164-166, 2000.

Mader, B. J.: A species level revision of Bridgerian and Uintan bronotheres (Mammalia, Perissodactyla) exclusive of Palaeosyops, Zootaxa, 1837, 1-85, 2008.

Mader, B. J.: Details of the cranial anatomy of a primitive diplacodont brontothere, cf. Protitanotherium, from the Wiggins Formation of Wyoming (Mammalia, Perissodactyla, Brontotheriidae), J. Vertebr. Paleontol., 29, 1224-1232, 2009a.

Mader, B. J.: The cranial anatomy of Metarhinus (Mammalia, Perissodactyla, Brontotheriidae), J. Vertebr. Paleontol., 29, 13001305, 2009b.

Mihlbacher, M. C.: Eubrontotherium clarnoensis, a new genus and species of brontothere (Brontotheriidae, Perissodactyla) from the Hancock Quarry, Clarno Formation, Wheeler County, Oregon, PaleoBios, 27, 19-39, 2007.

Mihlbacher, M. C.: Species taxonomy, phylogeny, and biogeography of the Brontotheriidae (Perissodactyla, Mammalia), Bulletin of the American Museum of Natural History, 311, 1-475, 2008.

Mihlbacher, M. C.: A new Uintan horned brontothere from Wyoming and the evolution of canine size and sexual dimorphism in the Brontotheriidae (Perissodactyla, Mammalia), J. Vertebr. Paleontol., 31, 202-214, 2011.

Mihlbacher, M. C. and Deméré, T. A.: A new species of Brontotheriidae (Perissodactyla, Mammalia) from the Santiago Formation (Duchesnean, middle Eocene) of Southern California, Proceedings of the San Diego Society of Natural History, 41, 136, 2009.

Mihlbacher, M. C. and Deméré, T. A.: Phylogenetic status of Metarhinus pater (Brontotheriidae: Perissodactyla) from southern California and species variation in Metarhinus from the 
Middle Eocene of North America, J. Vertebr. Paleontol., 30, 1229-1244, 2010.

Mihlbacher, M. C., Lucas, S. G., and Emry, R. J.: The holotype specimen of Menodus giganteus, and the "insoluble" problem of Chadronian brontothere taxonomy, in: Paleogene Mammals, edited by: Lucas, S. G., Zeigler, K. E., and Kondrashov, P. E., New Mexico Museum of Natural History and Science Bulletin, 26, 129-135, 2004.

Osborn, H. F.: The Mammalia of the Uinta Formation. Part III. The Perissodactyla, T. Am. Philos. Soc., 16, 505-530, 1889.

Osborn, H. F.: Fossil mammals of the Uinta Basin. Expedition of 1894, Bulletin of the American Museum of Natural History, 7, 71-105, 1895.

Osborn, H. F.: New or little known titanotheres from the Eocene and Oligocene, Bulletin of the American Museum of Natural History, 24, 599-617, 1908.

Osborn, H. F.: Lower Eocene titanotheres. Genera Lambdotherium, Eotitanops, Bulletin of the American Museum of Natural History, 21, 407-515, 1913.

Osborn, H. F.: Titanotheres of Ancient Wyoming, Dakota, and Nebraska, United States Geological Survey Monographs, 55, 1894, 1929.

Peterson, O. A.: A small titanothere from the lower Uinta beds, Annals of the Carnegie Museum, 9, 53-57, 1914a.

Peterson, O. A.: A new titanothere from the Uinta Eocene, Annals of the Carnegie Museum, 9, 29-52, 1914b.

Peterson, O. A.: New species of the genus Teleodus from the Upper Uinta of Northeastern Utah, Annals of the Carnegie Museum, 20, 307-312, 1931.

Peterson, O. A.: New titanotheres from the Uinta Eocene in Utah, Annals of the Carnegie Museum, 22, 351-361, 1934.

Rasmussen, D. T., Hamblin, A. H., and Tabrum, A. R.: The mammals of the Eocene Duchesne River Formation, in: Vertebrate Paleontology of Utah, edited by: Gillette, D. D., Utah Geological Survey Miscellaneous Publication 99-I, 422-427, 1999.

Riggs, E. S.: New or little known titanotheres from the lower Uintah formations with notes on the stratigraphy and distributions of fossils, Field Museum of Natural History, Geological Series 4, $17-41,1912$.
Robinson, P., Gunnell, G. F., Walsh, S. L., Clyde, W. C., Storer, J. E., Stucky, R. K., Froehlich, D. J., Ferrusquia-Villafranca, I., and McKenna, M. C.: Wasatchian through Duchesnean biochronology, in: Late Cretaceous and Cenozoic Mammals of North America, Biostratigraphy and Geochronology, edited by: Woodburne, M. O., Columbia University Press, New York, 106-155, 2004

Simpson, G. G.: Principles of Animal Taxonomy, Columbia University Press, New York, 1961.

Sprinkel, D.: Interim geologic map of the Vernal 30' $\times 60^{\prime}$ quadrangle, Uintah and Duchesne Counties, Utah, and Moffat and Rio Blanco Counties, Colorado, Scale 1 : 100 000, 2007.

Stock, C.: Titanothere remains from the Sespe of California, P. Natl. Acad. Sci. USA, 21, 456-462, 1935.

Stock, C.: Titanotheres from the Titus Canyon Formation, California, P. Natl. Acad. Sci. USA, 21, 456-462, 1936.

Stock, C.: An Eocene Titanothere from San Diego County, California, with remarks on the age of the Poway Conglomerate, P. Natl. Acad. Sci. USA, 23, 48-53, 1937.

Stock, C.: A titanothere from the type Sespe of California, P. Natl. Acad. Sci. USA, 24, 507-512, 1938.

Stovall, J. W.: Chadron vertebrate fossils from below the Rim Rock of Presidio County, Texas, Am. J. Sci., 246, 78-95, 1948.

Stucky, R. K., Prothero, D. R., Lohr, W. G., and Snyder, J. R.: Magnetic stratigraphy, sedimentology, and mammalian faunas of the early Uintan Washakie Formation, San Wash Basin, northwestern Colorado, in: The Terrestrial Eocene-Oligocene Transition, edited by: Prothero, D. R. and Emry, R. J., Cambridge University Press, Cambridge, 40-51, 1996.

Townsend, K. E., Friscia, A. R., and Rasmussen, D. T.: Stratigraphic distribution of upper Middle Eocene fossil vertebrate localities in the eastern Uinta Basin, Utah, with comments on Uintan Biostratigraphy, The Mountain Geologist, 43, 115-134, 2006. 